\title{
APOPTOSIS: IT'S POTENCIAL ROLE IN MATRIX DEGRADATION OF OSTEOARTHROTIC CARTILAGE
}

\author{
Kourí Flores JB., ${ }^{1,2}$ Abbud-Lozoya K.A
}

${ }^{1}$ Depto. de Patología Experimental, ${ }^{2}$ Unidad de Microscopia Electrónica, CINVESTAV-IPN, México D.F., ${ }^{3}$ Centro Nacional de Rehabilitación

Osteoarthrosis is a high morbidity and multifactor disease (1) characterized by focal degeneration of the articular cartilage. Nevertheless its pathogenia still needs to be unraveled. However, two major processes, among others, take place in the cartilage; matrix degradation $(2,3)$ and abnormal calcification of the subchondral bone. Both lead to cartilage loss and therefore joint malfunction. Apoptosis is present in OA cartilage (4-8) and it seems to be involved in the abnormal calcification of the subchondral bone (8). However, apoptosis has been recently reported to be restricted to the deep zone of the OA cartilage (9). Therefore its probable role in matrix degradation, remains debatable and needs to be elucidate.

It has been determined that matrix degradation is associated to the increased synthesis of metalloproteases located in the superficial and upper-middle zones of the cartilage $(2,3,5)$.

Studies in human OA cartilage showed positive TUNEL reaction for detecting DNA fragmentation typical of apoptosis in chondrocytes from the superficial and upper-middle zones of the tissue. In addition, preliminary results showed that chondrocytes from this anatomical exhibited an increased synthesis the of stromelysin-1 (SLN-1) and decreased activity of chondroitin sulfate 4,6 (CS-4,6). In addition, in our rat experimental OA model we found that severe OA-like damage correlated with two features: a) high number of TUNEL labeled chondrocytes within the entire depth of the tissue and b) to the rise of SLN-1 activity (11). All these results suggest that apoptosis might be related to matrix degradation.

References:

1-Thornill, TH., Schaffer J.L., (1993) Arthroplastia Inflamatorias y Degenerativas In: Orthopaethic Knowledge Update \# 4. Rosemont Illinois: American Academy Orthopaedic Surgeon; 89-106.

2-Pelletier, J.P., Faure, M.P., Di Batista, J.A., Roughley, P., Wilhelm, S., Visco, D., MartelPelletier, J. (1993) Am. J. Pathol. 142: 95-105.

3-Pelletier-Pelletier, J., MacCollum, R., Fujimoto, N., Obata, K., Cloutier, J.M., Pelletier, J.P., (1994) Lab. Invest. 70: 807-15.

4-Blanco, F.J., Guitian, R., Vázquez-Martul, E., de Toro, F.J., Galdo, F. (1998) Artritis. Rheum. 41: 284- 89.

5-Hashimoto, S., Ochs, R.L., Komiya, S., Lotz, M. (1998) Artritis. Rheum. 41:1632-38.

6-Hashimoto, S., Ochs, RL., Rosen, F., Quach, J., McCabe, G., Solan, J., Seegmiller, J.E., Terkeltaub, R., Lotz, M. (1998) Proc. Natl. Acad. Sci. USA, 95:3094-99.

7-Kouri, J.B., Rosales-Encina, J.L., Chaudhuri, P.P., Luna, J., Mena, R. (1997) Med. Sci. Res. 25: $245-48$.

8-Kouri, J. B., Aguilera, J.M., Reyes, J., Abbud, K.A., Gonsáles, S. (2000) J. Rheumatol. 27: 1005-19. 
9-Aigner, T.,Hemmel, M., Neureiter,D., Gebhard, P.M., Zeiler, G., Kircher, T., Mckenna. (2001) Arthritis \& Rheum. 44: 1304-12.

11-Abbud-Lozoya, K.A., Kouri, J.B., (2000) .Pathol. Res.Pract. 196, 729-45. 